\title{
Comparison between molecular and classical techniques for identification of Mycoplasma species isolated from mastitic ruminants
}

\author{
W. H. Hassan ${ }^{1}$, Mona A. El-Shabrawy ${ }^{2}$, E. G. Sadek ${ }^{2}$ \\ ${ }^{I}$ Department of Bacteriology, Mycology and Immunology, Faculty of Veterinary Medicine, Beni- \\ Suef University, Beni-Suef, Egypt and ${ }^{2}$ Department of Microbiology and Immunology, National \\ Research Centre, Cairo, Egypt
}

\begin{abstract}
A total of 165 cows, 19 buffaloes, 192 sheep and 118 goats were examined for detection of Mycoplasma mastitis. The results revealed that $114(69.59 \%)$ and $6(31.57 \%)$ were clinically mastitic cows and buffaloes respectively while $51(30.9 \%)$ and $13(68.42 \%)$ were apparently healthy cows and buffaloes respectively. On examining the apparently healthy cows and buffaloes, $67(32.84 \%)$ and $18(34.61 \%)$ were subclinically mastitic cows and buffaloes respectively. Mycoplasmas were isolated in percentages of $8.9 \%, 5.5 \%$ from subclinically mastitic cows and buffaloes respectively and in percentages of $12.97 \%, 12.5 \%$ from clinically mastitic cows and buffaloes respectively. M. bovis was isolated from $8(32 \%)$ and $M$. bovigenitalium from $7(28 \%)$ and $10(40 \%)$ unidentified Mycoplasma. Isolation of Mycoplasma from udder tissue in cows and buffaloes were in a percentage of $28.5 \%$ in cows while no Mycoplasma isolates were obtained from buffaloes' udder tissues. Application of PCR technique on these isolates and some of the negative samples was positive $100 \%$. On the other hand, the results revealed that 82 of $192(42.7 \%)$ and 43 of 118 (36.44) of the examined sheep and goats respectively were clinically mastitic. Isolation of Mycoplasma was from $11(13.41 \%)$ and $17(39.53 \%)$ of the examined sheep and goat respectively. Identification of these isolates revealed $8(29 \%) M$. agalactiae isolates and $20(71 \%)$ unidentified Mycoplasma spp. Application of PCR technique on traditionally identified M. agalactiae isolates revealed negative results on using $M$. agalactiae specific primer while positive results were obtained for the same 8 isolates $(\mathbf{1 0 0 \%})$ on using $M$. bovis specific primer.
\end{abstract}

Mycoplasmas cause many diseases in most species of the animals including human. In small ruminants, diseases induced by Mycoplasmas include respiratory diseases, mastitis, arthritis, genital diseases and eye lesions. The most important of these diseases are Contagious Caprine Pleuropneumonia (CCPP) and Contagious Agalactia (CA) which are designated by the Office of International Epizooties as list B diseases because of their economic impact on livestock (Nicholas, 2002).

Mycoplasmas are distinguished phenotypically from other bacteria by their minute size (125-150 millimicron) and total lack of a cell wall which explains many of the unique properties of the Mycoplasmas, such as sensitivity to osmotic shock and detergents, resistance to penicillin, and formation of peculiar fried-eggs shape colonies (Sabry, 2004). Mycoplasmas are pleomorphic. They can easily change their shape and may appear as

* Corresponding author. Tel.: +20 101546485; fax: +20822327982 .

E-mail address: dr_walidh@yahoo.com

(W.H.Hassan). pear-shaped or circular with characteristic "fried egg" shaped colonies.

Mycoplasma bovine, ovine and caprine mastitis are a highly contagious disease that results in milk loss and culling of infected animals (Cree, 2002).

Bradley et al., (2007) felt that the current literature did not warrant the widespread screening of mastitis cases for 'exotic' diagnoses, recommending that practitioners keep an open mind in the event of difficult to explain mastitis outbreaks and failures to respond to treatment.

Because of their importance in veterinary medicine, and since infection spreads quickly once it established in a herd, it is very important that specific and rapid diagnostic procedures are developed for their detections.

Identification of M. agalactiae and M. bovis by immunofluorescence was laborious and timeconsuming. Furthermore, M. agalactiae and $M$. bovis possess a particular ability to modify the phase and/or size of the membrane surface proteins, allowing escape of the host's 
immunodefence (Behrens, et al., 1994; Glew, et al., 2000).

The use of PCR in identification of $M$. bovis and $M$. agalactiae is quicker when compared with the conventional culture methods. In addition the Mycoplasmas can be detected even if the organs or the broth cultures were contaminated with bacteria. (Cardoso et al., 2000 and Hirose et al., 2001). The risk of false negative test results to a herd can be problematic. Conversely, the risk of false positive test results is reduced in view of the fact that non-pathogenic Mycoplasma species rarely cause mastitis (Kirk and Lauerman, 1994).

Incorrect identification by conventional diagnostic methods was recertified by PCR. Isolates from non-typical hosts, i.e. three $M$. bovis strains from small ruminants and two $M$. agalactiae strains from cattle, were characterized by sequencing the $16 \mathrm{~S}$ and part of the 23S ribosomal RNA genes (Bashiruddin, et al., 2005).

Consequently, this work was planned to clear out the comparison between classical methods and PCR technique in diagnosis of the false negative Mycoplasma isolates.

\begin{tabular}{ccccccc}
\hline Animals & Total No. & No. of & & \multicolumn{2}{c}{ Clinically mastitic } & \multicolumn{2}{c}{ Apparently healthy } \\
\cline { 4 - 7 } of milk & animals & Mamples & amples & $\begin{array}{c}\text { No. of } \\
\text { animals }\end{array}$ & $\begin{array}{c}\text { Milk } \\
\text { samples }\end{array}$ & $\begin{array}{c}\text { No. of } \\
\text { animals }\end{array}$ \\
\hline Cows & 335 & 165 & 131 & 114 & 204 & 51 \\
Buffaloes & 60 & 19 & 8 & 6 & 52 & 13 \\
Ewes & 192 & 192 & 82 & 82 & 110 & 110 \\
Goats & 118 & 118 & 43 & 43 & 75 & 75 \\
\hline
\end{tabular}

Cultivation of Mycoplasma: (Razin and Tully, 1983)

For udder tissues. A sample of the udder tissue was seared with a hot spatula to reduce surface contamination and about $0.5 \mathrm{~g}$ of the tissue was aseptically removed into a sterile mortar, cut into small pieces by a sterile scissor and was grinned with sterile sand, after which $5 \mathrm{ml}$ of broth medium was added.

A part of the mixture was directly plated (Plat 0) was made and about 0.2- $0.3 \mathrm{ml}$ was transferred into the broth (Broth 0). By the $3^{\text {rd }}$ day plate (0) and broth (0) were transferred into PPLO plate (1) and broth (1). On the sixth day, another plating was tried (Plate 3) beside an indirect plating (Plate 2) from the original broth on the $9^{\text {th }}$ day. From Broth (1) an inoculum was made into another broth tube (Broth 2) from which a last plating (Plate 4) was made. The agar plates were inoculated at $37^{\circ} \mathrm{C}$ under reduced oxygen tension in a $\mathrm{CO}_{2}$ incubator (5-

\section{Materials and methods}

Samples. A total number of 335 and 60 milk samples were collected from udder quarters of 165 and 19 examined cows and buffaloes respectively. 131 milk samples were collected from 114 clinically mastitic cows with abnormal secretions of mammary glands including clots or flakes in addition to udders swelling and hardness. 204 milk samples were collected from 51 apparently healthy cows which detected by palpation of udder and were subjected to California Mastitis Test (CMT) to detect subclinical mastitis. Eight milk samples were collected from 6 clinically mastitic buffaloes and 52 from 13 apparently healthy ones.

On the other hand a total number of 192 milk samples were collected from 82 mastitic and 110 apparently healthy ewes while a number of 118 milk samples were collected from 43 mastitic and 75 apparently healthy goats.

A total number of 80 udder tissues were collected belonged to cows, buffaloes, ewes and goats with numbers of $10,36,13$ and 20 respectively. $\left.10 \% \quad \mathrm{CO}_{2}\right)$. The plates were examined for suspected colonies after 48 hours under a stereomicroscope using oblique light and then on every other day up to 7- 10 days.

For milk samples. About $1 \mathrm{ml}$ of a well mixed milk sample was inoculated into $5 \mathrm{ml}$ broth, and a part of the mixture was directly plated (Plat 0 ) and about $0.2-0.3 \mathrm{ml}$ was transferred into the broth (Broth 0). By the $3^{\text {rd }}$ day plate $(0)$ and broth (0) were transferred into PPLO plate (1) and broth (1). On the sixth day, another plating was tried (Plate 3) beside an indirect plating (Plate 2) from the original broth on the $9^{\text {th }}$ day. From Broth (1) an inoculum was made into another broth tube (Broth 2) from which a last plating (Plate 4) was made. The agar plates were inoculated at $37^{\circ} \mathrm{C}$ under reduced oxygen tension in a $\mathrm{CO}_{2}$ incubator $\left(5-10 \% \mathrm{CO}_{2}\right)$. The plates were examined for suspected colonies after 48 hours under a stereomicroscope using oblique light and then on every other day up to 
7-10 days. Filtration with a syringe filter was used to overcome contaminated samples or fatty samples.

Differentiation between Mycoplasma and Acholeplasma isolates using the digitonin sensitivity test (Ernø and Stipkovits, 1973 a, b and Freundt, 1973).

Filter paper discs containing $0.02 \mathrm{ml}$ of a $1.5 \%$ ethanol solution of digitonin were placed on plates inoculated by the running drop technique with $0.1 \mathrm{ml}$ of cultures. The plates were incubated at $37^{\circ} \mathrm{C}$ in a moist $\mathrm{CO}_{2}$ incubator for 3 days, and then examined for the development of inhibition zones around the discs. Mycoplasma is digitonin sensitive, while Acholeplasma is digitonin resistant.

Biochemical characterization. It was performed according to Ern $\varnothing$ and Stipkovits (1973a, b).

Stereotyping of Mycoplasma by Growth Inhibition Test (GIT) (Clyde et al., 1984)

Filter paper discs soaked in $20 \mu \mathrm{l}$ of Mycoplasma agalactiae, Mycoplasma bovigenitalium and Mycoplasma bovis antisera were placed on the inoculated plates by the running drop technique. The plates were incubated at $37^{\circ} \mathrm{C}$ in $\mathrm{CO}_{2}$ incubator for 3-7 days. The interpretation was made by observing the zone of inhibition around the antisera discs.

Extraction of DNA by Chemical method using Phenol, Chlorophorm, Isoamyl: (Ausubel et al., 2003).

The centrifuged colony pellets were resuspended in $200 \mu \mathrm{l}$ sterile distilled water to which $200 \mu \mathrm{l}$ of lysis buffer was added. The mixture was vortexed efficiently then placed in a boiling water bath for 5 minutes. Equal volumes of phenol/choloroform/isoamyl alcohol $(25: 24: 1)$ was added and mixed by vortex then centrifuged at $12.000 \mathrm{rpm}$ for 10 minutes. After centrifugation, 3 layers were separated (an aqueous layer containing the DNA, a creamy layer containing the proteinous material, a rosy yellow layer containing phenol). The aqueous layer was transferred to a fresh tube at which an equal volume of phenol/ choloroform/isoamyl alcohol (25:24:1) was added and mixed by vortex then centrifuged at $12.000 \mathrm{rpm}$ for 10 minutes, this step was repeated till the middle proteinous layer disappeared. The aqueous layer was transferred to a fresh tube with the addition of equal volumes of choloroform/isoamyl alcohol (24:1) and mixed by vortex then centrifuged at $12.000 \mathrm{rpm}$ for 10 minutes. The aqueous layer was transferred to a fresh tube with an equal volume of isopropanol was added and mixed gently. After storage at $-20^{\circ} \mathrm{C}$ for 1 hour, the DNA was pelleted at $12.000 \mathrm{rpm}$ for 20 minutes, followed by washing with $70 \%$ ethanol and recentrifugation at $12.000 \mathrm{rpm}$ for 10 minutes. The DNA pellet was dried and resuspended in $50 \mu$ deionized distilled water.

Running of PCR: (Riffon et al., 2001)

The amplified reactions were performed in $50 \mu 1$ volumes in micro amplification tubes (PCR tubes). The reaction mixture consisted of $10 \mu \mathrm{l}$ (200 ng) of extracted DNA template from bacterial cultures, $5 \mu 1$ 10x PCR buffer, $1 \mu 1$ dNTPs $(40 \mu \mathrm{M}), 1 \quad \mu \mathrm{l}$ Ampli Taq DNA polymerase, $1 \mu \mathrm{l}(50 \mathrm{pmol})$ from each primer pairs (each primer pair was used separately) and the volume of the reaction mixture was completed to $50 \mu \mathrm{l}$ using deionized distilled water and the thermal cycler was adjusted as follows:

For M. bovis initial denaturation at $94^{\circ} \mathrm{C}$ for 2 minutes followed by 30 cycles of denaturation at $94^{\circ} \mathrm{C}$ for 30 seconds, annealing step at $52^{\circ} \mathrm{C}$ for 1 minute and extension at $72^{\circ} \mathrm{C}$ for 150 seconds. A final extension step was done at $72^{\circ} \mathrm{C}$ for 5 minutes. The PCR products were stored in the thermal cycler at $4^{\circ} \mathrm{C}$ until they were collected. The amplified product size equals to $227 \mathrm{bp}$ for M. bovis and loads $10 \mu \mathrm{l}$ from PCR products.

For M. agalactiae : initial denaturation at $94^{\circ} \mathrm{C}$ for 4 minutes followed by 30 cycles of denaturation at $94^{\circ} \mathrm{C}$ for 60 seconds, annealing step at $57^{\circ} \mathrm{C}$ for 60 seconds and extension at $65^{\circ} \mathrm{C}$ for 60 seconds. A final extension step was done at $65^{\circ} \mathrm{C}$ for 10 minutes. The PCR products were stored in the thermal cycler at $4^{\circ} \mathrm{C}$ until they were collected.

Screening of PCR products by agarose gel electrophoresis. (Sambrook et al., 1989). The PCR products were electrophoresed in $2 \%$ agarose gel using Tris-borate EDTA buffer. The gel containing separated DNA was stained with ethidium bromide and examined under short wave UV transilluminator; Standard marker containing known fragments of DNA either 100 bp or $250 \mathrm{bp}$ ladders was used.

Oligonucleotide primers used for amplification of DNA recovered from Mycoplasma bovis isolates. The PCR amplicone was a part of $M$. bovis DNA sequence, with the following primer sequences these primers amplify a 227 bp fragment. (Yassin et al., 2004). Forward $5^{`}$ GCA ATA TCA TAG CGG CGA AT $3^{\backslash}$ Reverse 
$5^{\prime}$ TCT CAA CCC CGC TAA ACA TC 3

Oligonucleotide primers used for amplification of DNA recovered from Mycoplasma agalactiae isolates. The PCR amplicone was a part of $M$. agalactiae DNA sequence, with the following primer sequences: these primers amplify a $375 \mathrm{bp}$ fragment. (Tola et al.,1996).

Forward

\section{5'AAA GGT GCT TGA GAA ATG GC3}

\section{Reverse}

\section{5'GTT GCA GAA GAA AGT CCA ATCA3}

Results and discussion

From the results presented in Table (1) the mastitic cows were 114 out of the examined 165 $(69.1 \%)$. On the other hand the mastitic buffaloes were 6 out of 19 (31.6\%), these results were in agreement with those reported by Osman et al., (2009). Table (2) revealed that, out of 204 apparently normal quarter milk samples collected from 51 apparently healthy cows, subclinical mastitis reached 67 with an incidence of $(32.84 \%)$, and 137 were negative for CMT with an incidence of $(67.16 \%)$, On the other hand out of 52 apparently normal quarters milk samples of buffaloes, 18 were subclinically mastitic with an incidence of $(34.61 \%)$. These results were nearly similar to those obtained by Kamelia et al., (2008); Bachaya et al., (2005), who reported subclinical mastitis in 32.62 and $26.25 \%$ of cows and buffaloes, respectively.

Results in table (3) demonstrated that 82 out of 192 examined ewes and 43 out of 118 examined goats were clinically mastitic $(42.7 \%$ and $36.4 \%$ respectively). These results were in agreement with Iqbal et al., (2004).

Table (4) revealed that the recovered Mycoplasma isolates from subclinically mastitic cows were 6 (8.9\%) while 1 (5.5\%) Mycoplasma isolate was recovered from subclinically mastitic buffaloes. On the other hand, the incidence of Mycoplasma in clinically affected quarter milk samples of cows and buffaloes were 17 $(12.97 \%)$ and one $(12.5 \%)$ respectively, a similar results obtained by Gonzalez and Wilson (2003).

The results in table (5) revealed that in the clinical stage the total number of Mycoplasma isolates were $11(13.41 \%)$ from sheep while 17 (39.53\%) Mycoplasma isolates were recovered from goats, and this agreed with Otlu, (1997).

Table (6) showed the results of biochemical and serological identification of Mycoplasma species isolated from the examined cows and buffaloes. M. bovis was isolated in a percentage of 32 while $(28 \%)$ of the isolates were $M$. bovigenitalium and unidentified Mycoplasmas were $40 \%$. These results agreed with that of Biddle et al., (2003) and disagreed with Kamelia et al., (2008). On the other hand the results in table (7) revealed that Mycoplasma agalactiae recovered from mastitic sheep and goats were (29\%) and unidentified Mycoplasma were $(71 \%)$. These results were in agreement with Iqbal et al., (2004).

Table (1): Incidence of clinical mastitis among the examined lactating cows and buffaloes.

\begin{tabular}{lccccc}
\hline \multirow{2}{*}{ Animal species } & \multicolumn{4}{c}{ Udder status } & \multirow{2}{*}{ Total } \\
\cline { 2 - 5 } & \multicolumn{2}{c}{ Apparently healthy } & \multicolumn{2}{c}{ Mastitic } & \\
\cline { 2 - 5 } & \multicolumn{1}{c}{ No. } & $(\%)$ & No. & $(\%)$ & \\
\hline Cows & 51 & $30.9 \%$ & 114 & $69.1 \%$ & 165 \\
Buffaloes & 13 & $68.4 \%$ & 6 & $31.6 \%$ & 19 \\
\hline
\end{tabular}

Table (2): Incidence of subclinical mastitis among cows and buffaloes as detected by CMT.

\begin{tabular}{cccccc}
\hline \multirow{2}{*}{$\begin{array}{c}\text { Animal } \\
\text { Species }\end{array}$} & \multicolumn{2}{c}{ Subclinically mastitic quarters } & \multicolumn{2}{c}{ Normal quarters } & \multirow{2}{*}{ Total } \\
\cline { 2 - 5 } & No. & $(\boldsymbol{\%})$ & No. & $(\boldsymbol{\%})$ & \\
\hline Cows & 67 & 32.8 & 137 & 67.2 & 204 \\
Buffaloes & 18 & 34.6 & 34 & 65.4 & 52 \\
\hline
\end{tabular}

$\%$ was calculated according to the total number of the examined apparently normal milk samples.

Table (3): Incidence of clinical mastitis among sheep and goats.

\begin{tabular}{|c|c|c|c|c|c|}
\hline \multirow{3}{*}{ Animal species } & \multicolumn{4}{|c|}{$\begin{array}{r}\text { Udder status } \\
\end{array}$} & \multirow{3}{*}{ Total } \\
\hline & \multicolumn{2}{|c|}{ Apparently healthy } & \multicolumn{2}{|c|}{ Mastitic } & \\
\hline & No. & $(\%)$ & No. & $(\%)$ & \\
\hline Sheep & 110 & $57.3 \%$ & 82 & $42.7 \%$ & 192 \\
\hline Goats & 75 & $63.6 \%$ & 43 & $36.4 \%$ & 118 \\
\hline
\end{tabular}


Table (4): Incidence of Mycoplasma in subclinically and clinically mastitic cows' and buffaloes' quarter milk samples.

\begin{tabular}{|c|c|c|c|c|c|c|}
\hline \multirow{4}{*}{ Species } & \multicolumn{6}{|c|}{ Quarter status } \\
\hline & \multicolumn{3}{|c|}{ Subclinically mastitic } & \multicolumn{3}{|c|}{ Clinically mastitic } \\
\hline & \multirow{2}{*}{$\begin{array}{c}\text { Examined } \\
\text { OMS }\end{array}$} & \multicolumn{2}{|c|}{ Positive QMS } & \multirow{2}{*}{$\begin{array}{c}\text { Examined } \\
\text { OMS }\end{array}$} & \multicolumn{2}{|c|}{ Positive QMS } \\
\hline & & No. & $\%$ & & No. & $\%$ \\
\hline Cows & 67 & 6 & 8.9 & 131 & 17 & 12.97 \\
\hline Buffaloes & 18 & 1 & 5.5 & 8 & 1 & 12.5 \\
\hline
\end{tabular}

QMS= Quarters Milk Samples

$\%$ was calculated according to the total number (No.) of examined quarter milk samples.

Table (5): Incidence of Mycoplasma in clinically mastitic sheep and goats.

\begin{tabular}{cccc}
\hline \multirow{2}{*}{ Animal species } & Total No. & \multicolumn{2}{c}{ Mycoplasma +ve animals } \\
\cline { 3 - 5 } & Examined & No. & \% \\
\hline Sheep & 82 & 11 & 13.41 \\
Goat & 43 & 17 & 39.53 \\
\hline
\end{tabular}

$\%$ was calculated according to the total number (No.) of examined milk samples.

Table (6): Biochemical and serological identification of Mycoplasma isolates recovered from mastitic cows and buffaloes.

\begin{tabular}{|c|c|c|c|c|c|c|}
\hline \multirow{2}{*}{ Types of Mycoplasma isolates } & \multirow{2}{*}{ D.S } & \multirow{2}{*}{ U.A } & \multirow{2}{*}{ G.F. } & \multirow[t]{2}{*}{ A.H. } & \multicolumn{2}{|c|}{$\begin{array}{c}\text { Positive isolates } \\
\text { (GIT) }\end{array}$} \\
\hline & & & & & No. & $\%$ \\
\hline M. bovis & + & - & - & - & 8 & 32 \\
\hline M. bovigenitalium & + & - & - & - & 7 & 28 \\
\hline Unidentified Mycoplasma & + & & & & 10 & 40 \\
\hline $\begin{array}{c}\text { Total } \\
\end{array}$ & & & & & 25 & 100 \\
\hline $\begin{array}{l}\text { D.S. = Digitonin sensitivity. } \\
\text { G.F. = Glucose fermentation. }\end{array}$ & & $\begin{array}{l}\text { U.A. }= \\
\text { A.H. }=\end{array}$ & & & & \\
\hline
\end{tabular}

Table (7): Biochemical and serological identification of Mycoplasma isolates recovered from mastitic sheep and goats.

\begin{tabular}{lcccccc}
\hline \multirow{2}{*}{ Types of Mycoplasma isolates } & \multirow{2}{*}{ D.S } & \multirow{2}{*}{ U.A } & \multirow{2}{*}{ G.F. } & \multicolumn{2}{c}{ A.H. } & \multicolumn{2}{c}{ Positive isolates (GIT) } \\
\cline { 5 - 7 } & & & & & No. & $\%$ \\
Mnidentified Mycoplasma & + & - & - & - & 8 & 29 \\
Total & + & & & & 20 & 71 \\
\hline
\end{tabular}

D.S. = Digitonin sensitivity. U.A. = Urease activity

G.F. $=$ Glucose fermentation $\quad$ A.H. $=$ Arginin hydrolysis

$+\mathrm{ve}$ * number of isolates positive to specific antisera by Growth inhibition test (GIT).

Table (8): Biochemical and serological identification of Mycoplasma isolates recovered from udder tissues of cows and buffaloes.

\begin{tabular}{|c|c|c|c|c|c|c|c|}
\hline \multirow{2}{*}{$\begin{array}{l}\text { Animal } \\
\text { species }\end{array}$} & \multirow{2}{*}{$\begin{array}{l}\text { No. of examined } \\
\text { udder tissue } \\
\text { samples }\end{array}$} & \multirow[t]{2}{*}{ D.S } & \multirow[t]{2}{*}{ U.A } & \multirow[t]{2}{*}{ G.F. } & \multirow[t]{2}{*}{ A.H. } & \multicolumn{2}{|c|}{ Positive isolates } \\
\hline & & & & & & No. & $\%$ \\
\hline Cows & 10 & + & - & - & - & 2 & 20 \\
\hline Buffaloes & 36 & & & & & 0 & 0 \\
\hline
\end{tabular}

D.S. $=$ Digitonin sensitivity. $\quad$ U.A. $=$ Urease activity.

G.F. $=$ Glucose fermentation $\quad$ A.H. $=$ Arginin hydrolysis

$+\mathrm{ve} *$ number of isolates positive to specific antisera by Growth inhibition test. 
Bacteriological examination of 13 and 20 udder tissue samples of sheep and goats respectively recovered no Mycoplasma isolates.

PCR and culture methods were applied for 11 milk samples $(10+1$ reference sample $)$ for the identification of the Mycoplasmas isolated from bovine milk. The results showed that out of the 11 samples, only 8 samples were positive culture while the remaining 3 were negative. On the other hand all the eleven samples were positive for PCR using $M$. bovis primers as illustrated in Table (9) and Photo (1).

On the other hand the eight $M$. agalactiae isolates which identified by cultural and serological methods were negative by PCR using specific $M$. agalactiae primers and use reference strain to $M$. agalactiae while the same 8 isolates were positive by PCR using $M$. bovis primers (Table $10 \&$ Photo 2 ).
As shown in table (10) there is a clear relation between $M$. bovis and $M$. agalactiae. However in the present study $8 \mathrm{M}$. agalactiae isolates isolated from milk of sheep and goats were identified using cultural, biochemical and serological tests. On contrast the application of PCR to these isolates, using specific primers for $M$. agalactiae revealed negative results, while using $M$. bovis specific primers to the same isolates revealed positive results for all isolates (Photo 2\&3). According to the obtained results and the previous literatures in Egypt it is considered the first record to isolate $M$. bovis from sheep and goats milk, these results were in agreement with (Kumar and Singh, 1984; Chima et al., 1986 and Richard et al., 1989) who succeeded to isolate $M$. bovis from sheep and goats.

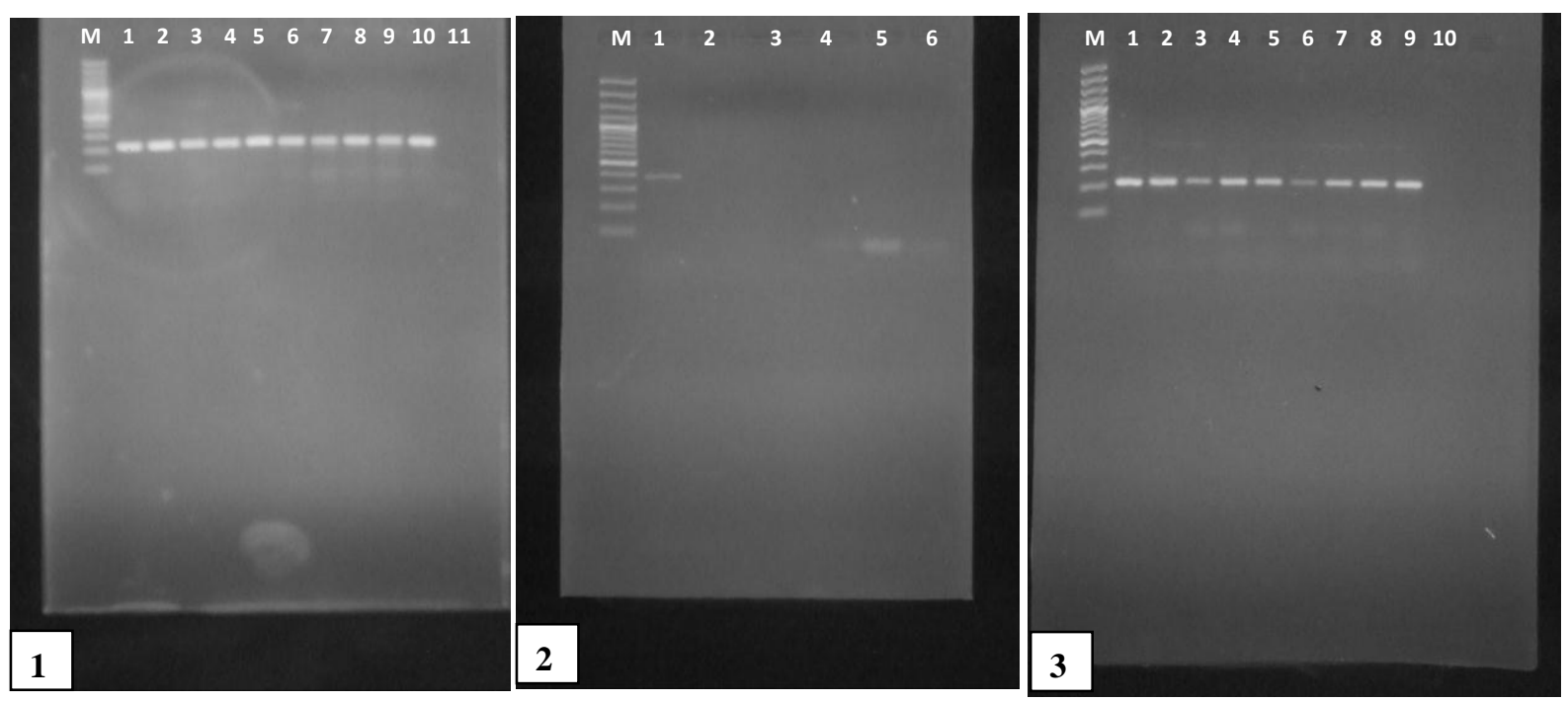

Photo (1): Agarose gel electrophoresis showing amplification of the $227 \mathrm{bp}$ fragments of $M$. bovis from the extracted DNA of $M$. bovis isolates.

Lane $\mathrm{M}$ shows the $100 \mathrm{bp}-1.5 \mathrm{~Kb}$ DNA ladder.

Lanes 1-11 show amplification of the $227 \mathrm{bp}$ fragment of M. bovis (Lane 1: Reference strain as positive control, lanes 2-10: tested samples and lane 11 is a negative control).

Photo(2): Agarose gel electrophoresis showing amplification of the $375 \mathrm{bp}$ fragment of M. agalactiae from the extracted DNA of $M$. agalactiae reference strain.

Lane M: shows the $100 \mathrm{bp}-1.5 \mathrm{~Kb}$ DNA ladder.

Lanes 1-7 show amplification of the 375 bp fragment of M. agalactiae (Lane 1: M. agalactiae reference strain, Lanes 2-6 showing negative results for tested isolates and lane 7 is a negative control).

Photo. (3). Agarose gel electrophoresis showing amplification of the $227 \mathrm{bp}$ fragment of of M. bovis from the extracted DNA of $M$. bovis reference strain.

Lane M showing the $100 \mathrm{bp}-1.5 \mathrm{~Kb}$ DNA ladder.

Lane 1: M. bovis reference strain.

Lanes 2-9 showing amplification of the $227 \mathrm{bp}$ fragment of M. bovis from the extracted DNA of other

Mycoplasma agalactiae (which gives positive culture and negative PCR agalactiae).

Lane 10 showing no amplification of the $227 \mathrm{bp}$ fragment of $\mathrm{M}$. bovis (negative control). 
The incorrect identification by conventional diagnostic methods was recertified by PCR. Bashiruddin et al., (2005) reported isolates from non-typical hosts, i.e. three $M$. bovis strains from small ruminants and two $M$. agalactiae strains from cattle, were characterized by sequencing the $16 \mathrm{~S}$ and part of the $23 \mathrm{~S}$ ribosomal RNA genes.

Table (9): Results of PCR (M. bovis) and culture for bovine milk samples.

\begin{tabular}{cccc}
\hline Examination & Positive & Negative & Total \\
\hline Culture & 8 & 3 & 11 \\
PCR $($ M. bovis $)$ & 11 & 0 & 11 \\
\hline
\end{tabular}

Table (10): Results of culture and PCR (M. agalactiae and M. bovis) for milk samples of sheep and goats.

\begin{tabular}{lccc}
\hline Examination & Positive & Negative & Total \\
\hline Culture & 8 & 0 & 8 \\
PCR $(M$. bovis $)$ & 8 & 0 & 8 \\
PCR $(M$. agalactiae $)$ & 0 & 8 & 8 \\
\hline
\end{tabular}

\section{Conclusion}

In conclusion, Mycoplasmas were slow to grow and difficult to culture. Traditionally, very complex media had been used for culture, based on rich growth media have recently been found to be inhibitory in some cases. Incubation and observation should continue for 7-10 days before plates were considered negative and false-negative results were common due to low numbers of organisms in the sample, or the fragility of Mycoplasma itself. Although serological methods are easier to perform and less costly, However, they are also generally non-specific, insensitive, and retrospective. PCR-based technology for Mycoplasma yields the highest level of sensitivity and specificity. The detection of Mycoplasma spp in cattle, buffaloes, sheep and goats by polymerase chain reaction (PCR) was based on the in vitro amplification of the highly-conserved 16S rRNA gene, so using PCR technique to differentiate between $M$. bovis and M. agalactiae because of the close relation between each other and this technique is rapid, sensitive and specific. Recommended future work is to apply PCR technique directly on milk samples and udder tissues to make a comparison between results of culture and PCR.

\section{References}

Ausubel, F.M.; Brent, R.; Kingston, R.E.; Moore, D.D.; Seidman, J.G.; Smith, J.A. and Struhl, K. (2003): Current protocols in molecular biology, John Wiley \& Sons, New York, N.Y.

Bachaya, H.A.; Iqbal, Z.; Muhammed, G.; Yousaf, A. and Ali. M.M. (2005): Subclinical mastitis in buffaloes in attack District of Punjab (Pakistan). Vet. J., 25 (3). 134 136
Bashiruddin, J.B.; Frey, J.; Konigsson, M.H.; Johansson, K.E.; Hotzel, H.; Diller, R.; de Santis, P.; Botelho, A.; Ayling, R.D.; Nicholas, R.A.; Thiaucourt, F. and Sachse, K. (2005): Evaluation of PCR systems for the identification and differentiation of Mycoplasma agalactiae and Mycoplasma bovis: a collaborative trial. Vet. J., 169: 268-275.

Behrens A.; Heller, M.; Kirchhoff, H.; Yogev, D. and Rosengarten R.A. (1994): Family of phase- and sizevariant membrane surface lipoprotein antigens (Vsps) of Mycoplasma bovis. Infect. Immune., 62:5075-5084.

Biddle, M.K.; Fox, L.K. and Hancock, D.D. (2003): Patterns of Mycoplasma shedding in the milk of dairy cows with intramammary Mycoplasma infection. J. Am. Vet. Med. Assoc., 223: 1163-1166.

Bradley, A.J.; Leach, K.A.; Breen, J.E.; Green, L.E. and Green, M.J. (2007): Survey of the incidence and etiology of mastitis on dairy farms in England and Wales. Vet. Rec., 160: 253-258.

Cardoso, V.M.; Blanchard, A.; Ferris, S.; Verlengia, R.; Timenetsky, J. and Florio Da Cunha, R.A. (2000): Detection of Ureaplasma diversum in cattle using a newly developed PCR-based detection assay. Vet. Microbiol., 72: 241-250.

Chima, J.C., Ern̈, H. and Ojo, M.O. (1986): Characterization and Identification of caprine, genital mycoplasmas. Acta Veterinaria Scandinavica, 27: 531-539. Clyde, W.A.; Kenny, G.E.Jr. and Schachter, J. (1984): Cumitech 19, Laboratory diagnosis of chlamydia and mycoplasmal infections. Coordinating (ed.) WL. Drew. ASM. Washington, DC.

Cree, J.L. (2002): Mycoplasma Mastitis: Facts Every Producer Should Know. Jersey J., 1- 4.

Ernø, H. and Stipkovits, L. (1973a): Bovine mycoplasmas: cultural and biochemical studies. I. Acta Vet. Scand., 14: 436-449.

Ernø, H. and Stipkovits, L. (1973b): Bovine mycoplasmas: cultural and biochemical studies. II. Acta Vet. Scand., 14: 450-463.

Freundt, E.A. (1973): Principles of Mycoplasma classification. Ann. N.Y. Acad. Sci., 225: 713.

Glew, M.D.; Papazisi, L.; Poumarat, F.; Bergonier, D.; Rosengarten, R. and Citti, C. (2000): Characterization of 
a multi-gene family undergoing high frequency DNA rearrangements and coding for abundant variable surface proteins in Mycoplasma agalactiae. Infect Immun., 68:4539-4548.

Gonzalez, R.N. and Wilson, D.J. (2003): Mycoplasmal mastitis in dairy herds. Vet. Clin. North. Am. Food Anim. Pract., 19: 199-221.

Hirose, K.; Kawasaki, Y.; Kotani, K.; Tanaka, A.; Abiko, K. and Ogawa, H. (2001): Detection of Mycoplasma in mastitic milk by PCR analysis and culture method. J. Vet. Med. Sci., 63.

Iqbal, M.; Ali. M.; Daraz, B. and Siddique, K. (2004): Bacteriology of mastitis milk and in vitro Antibiogram of the isolates. Vet. J., 24 (4) 161-164.

Kamelia, M.O.; Abd-Elrazik, K.A.; Barbar, E.E.; Elshafeey Dina, Y. and Amany, A.A. (2008): Molecular typing of Mycoplasma species recovered from bovine mastitis. Global vet. J., 2(6) 360-368.

Kirk, J.H. and Lauerman, L.H. (1994): Mycoplasma mastitis in dairy cows. Compend. Contin. Educ. Pract. Vet., 16: 541-558.

Kumar, N. and Singh, B. (1984): Mycoplasma infection in genital system of bovines. Ind. J. Anim. Sci., 54, 310-314.

Nicholas, R.A. (2002): Improvements in the diagnosis and control of diseases of small ruminants caused by mycoplasmas. Sma Rum. Res., (45):145-149.

Osman, K.M.; El-Enbaawy, M.I.; Ezzeldeen, N. and Hussein. H.M. (2009): Mastitis in dairy buffaloes and cattle in Egypt. Am. J. Vet. Res.

Otlu, S. (1997): Isolation, identification and antibiotic sensitivity of mycoplasmas from cases of pneumonia in sheep in the Kars district. Etlik. Vet. Mikrobe. Dergisi., 9(1): 157-174.

Razin, S. and Tully, J.G. (1983): Text book Methods in Mycoplasmology Vol. II .Acad. Press. INC.

Richard, Y., Borges, E., Favier, C. and Oudar, J. (1989): Nasal and Pulmonary flora in a goat. Annales Recherche Veterinaire 20: 269-276.

Riffon, R.; Sayasisth, K.; Khalil, H.; Dubereuil, P.; Droletr, M. and Lagace, J. (2001): Development of a rapid and sensitive test for identification of major pathogens in bovine mastitis by PCR. J. Clin. Microbiol., 39: 2854-2586.

Sabry, M.Z. (2004): Avian Mycoplasmas: Role in disease diagnosis and current control strategies. P101-129 In: A.A. Sami Ahmed; M.Z. Sabry; A.A. El-Gohary and M.M. Hashim (Ed). Proceeding of Sixth scientific conference of the Egyptian veterinary poultry association. Sep. 25-27, Cairo, Egypt.

Sambrook, J.; Fritsch, E.F. and Maniatis, T. (1989): Molecular Cloning. A laboratory Manual. $2^{\text {nd }}$ Ed., Cold Spring Harbor Laboratory, Press, New York.

Tola, S.; Idini, G.; Manunta, D.; Galleri, G.; Angioi, A. and Rocchigiani A.M. (1996): Rapid and specific detection of Mycoplasma agalactiae by polymerase chain reaction. Vet Microbiol., 51:77-84.

Yassin, M.H.; Amin, A.S. and Ibrahim, A.K. (2004): Molecular diagnosis of bovine mycoplasma mastitis.Proc. The first Intern. Conf. Vet.Res.Div., NRC, Cairo, Egypt, February 15-17, 38-47.

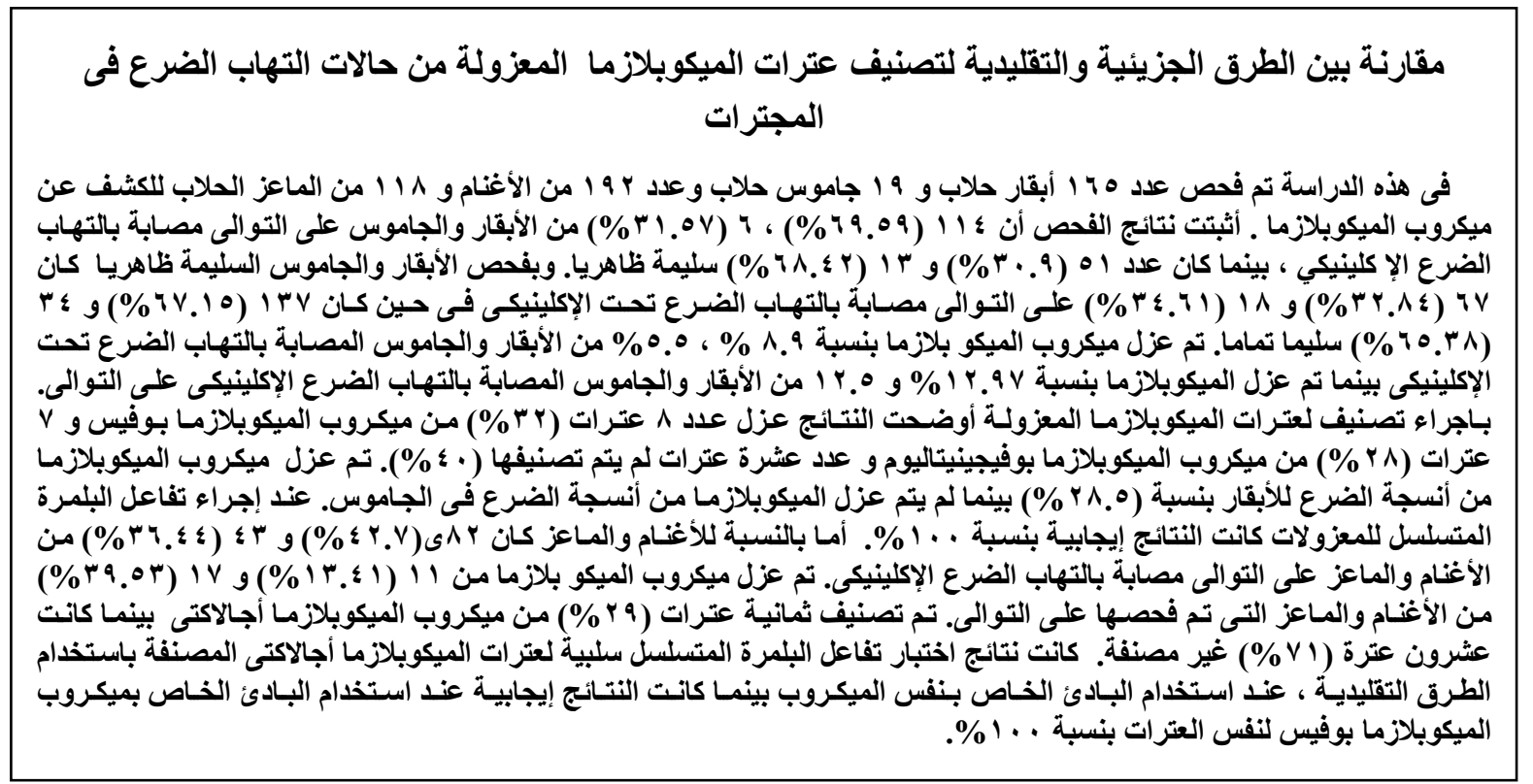

